American Journal of Pharmaceutical Education 2020; 84 (5) Article 7906.

\title{
COMMENTARY
}

\section{Getting Rigor Right}

\author{
Tyler M. Rose, $\mathrm{PhD}^{\mathrm{a}, \mathrm{b}}$ \\ ${ }^{a}$ Roseman University of Health Sciences College of Pharmacy, South Jordan, Utah \\ ${ }^{\mathrm{b}}$ Editorial Board Member, American Journal of Pharmaceutical Education, Arlington, Virginia \\ Submitted October 30, 2019; accepted October 31, 2019; published May 2020.
}

\begin{abstract}
A colleague of mine once shared a story he heard of an organic chemistry teacher who would tell people he had one of the most important, lifesaving jobs in the world. Why? Because he made sure academically unprepared premed students never made it to medical school. Teachers can have many possible motivations for maintaining high academic standards in their courses. A desire to ensure future health practitioners are adequately prepared to engage in the intellectual rigor of their profession may be just one of them.
\end{abstract}

Keywords: academic rigor, course rigor, rigor

The word rigor is commonly invoked in academia, but is not easily defined in that context. For example, the concept is used by the Accreditation Council for Pharmacy Education (ACPE) to describe the didactic requirements of the pharmacy curriculum (emphasis added): "The didactic portion of the Pre-APPE curriculum includes rigorous instruction in all sciences that define the profession. ..." The term rigor mortis hints at the literal Latin meaning of the word: stiffness. ${ }^{2}$ Colloquially, it is understood to be a measure of how tough a class is. But class difficulty can be contrived as the result of practices such as requiring students to submit large quantities of work in a short amount of time, providing insufficient help to students, providing only high-stakes summative rather than low-stakes formative feedback, testing students on material only scantily covered in class, or testing at a higher cognitive level than that for which students were prepared. ${ }^{3}$ A more sound basis for defining academic rigor was provided by Draeger and colleagues as the process of "actively learning meaningful content with higher-order thinking at the appropriate level of expectation."

In today's pharmacy teaching environment, setting appropriate learning expectations for a diverse classroom of learners with varying degrees of academic preparedness is not straightforward; and, for teachers, a variety of practical motivational factors may come into play when establishing course rigor. Lewin's force field analysis model is a useful tool for considering these motivational

Corresponding Author: Tyler M. Rose, Roseman University of Health Sciences College of Pharmacy, 10920 S. River Front Pkwy., South Jordan, UT 84095. Tel: 801-878-1075. Email: trose@roseman.edu. factors. ${ }^{5}$ This model posits that an equilibrium exists between driving forces and restraining forces, and that change will occur when one set of forces exceeds the other. A non-comprehensive list of potential motivational forces related to course rigor has been proposed in Figure 1 .

The sum of the vector directions and magnitudes in Figure 1 determines the resultant level of course rigor, which usually lies within a generally accepted range, often determined, at least in part, by programmatic, organizational, and governmental standards. For example, ACPE provides guidance on student attrition, in excess of which programs are required to identify the root cause and generate an action plan to address it. ${ }^{6}$ On the other extreme, the North American Pharmacist Licensure Examination (NAPLEX) provides a means for assessing the competence of students before they are admitted to practice. ${ }^{7}$ Inappropriate levels of course rigor can adversely affect students. If standards are too low, students may have difficulty succeeding in more advanced courses in the program, including experiential courses, and may struggle to pass the NAPLEX. If standards are too high, it may result in unnecessarily exaggerated student attrition rates, student stress, ${ }^{8-10}$ and possibly increased incidences of academic dishonesty. ${ }^{11}$

Internal driving and restraining forces like those suggested in Figure 1 may subtly, even subconsciously, drift over time, resulting in a shift in course rigor. However, once brought to the attention of the faculty, motivational forces can be intentionally managed to provide a resultant that is fair and equitable and based on rational, ethical principles. A perusal of the list of motivational factors in Figure 1 suggests some factors might be best moderated at the program level, while others could be more appropriate for individual management. 


\section{American Journal of Pharmaceutical Education 2020; 84 (5) Article 7906.}

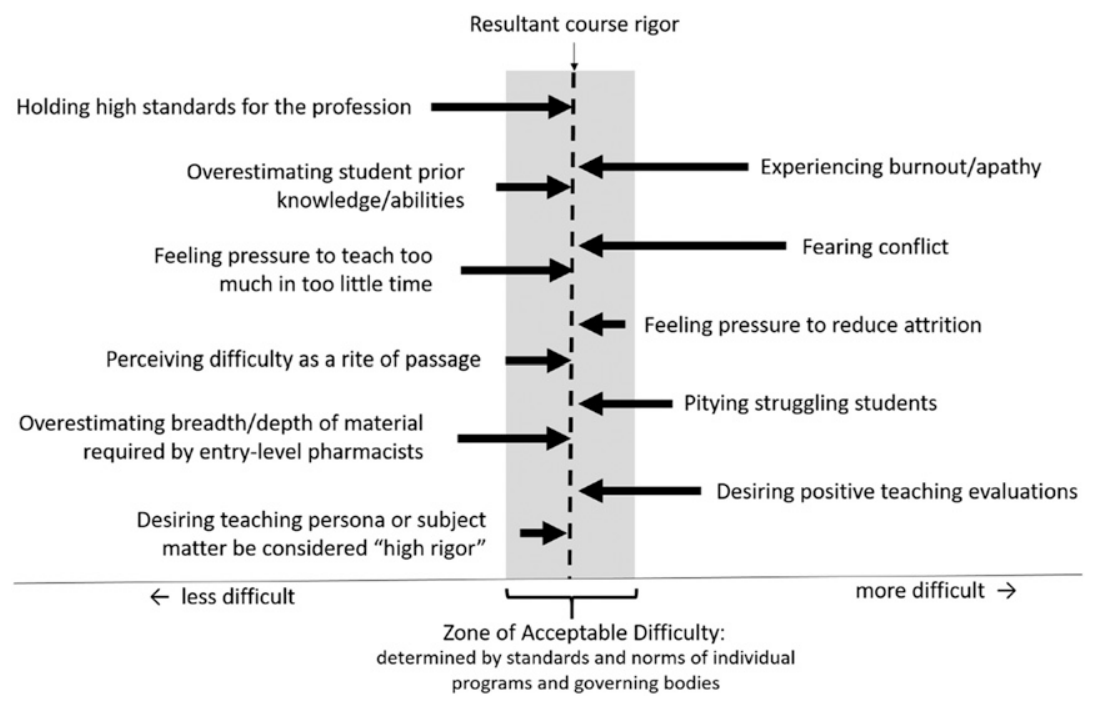

Figure 1. A Hypothetical Illustration on How Instructor Motivation Might Impact Course Rigor

Programs can help when it comes to the pressures of having too much to teach in not enough time, a lack of academic support for struggling students, attrition concerns, or a perceived need to receive glowing student evaluations of teaching. Curriculum designers can use feedback to ensure an appropriate match between time allotted and content, and to ensure learning objectives are relevant and delivered at an appropriate level for student pharmacists. College administrators can ensure that struggling students have adequate access to quality academic support services and that fair, consistently applied procedures for inadequate academic progress are in place. Policies and procedures can be crafted to strike a balance between the weight carried by student evaluations of teaching versus other evidence of teaching quality in faculty annual reviews and in promotion and tenure guidelines.

At the individual level, faculty members can engage in self-evaluation and personal reflection to continually refine the levels of academic rigor in their courses. Together with those in charge of programmed faculty development, faculty members can seek to improve their knowledge and skills in regard to establishing appropriate educational expectations and eliminating instances of contrived rigor, ${ }^{12-14}$ writing fair test questions and evaluating these questions statistically, ${ }^{15}$ evaluating student prior knowledge, ${ }^{16}$ and using instructional methods that benefit underprepared learners. ${ }^{17-19}$

Given the adverse consequences that can arise from either abandonment or accretion of academic rigor, it is important for individual faculty members and their programs to make an effort to identify and minimize gaps in knowledge and skills, maladaptive motivations, and any perverse incentives that may be working against maintaining appropriate levels of academic rigor in their pharmacy classrooms.

\section{REFERENCES}

1. Accreditation Council for Pharmacy Education. Accreditation standards and key elements for the professional program in pharmacy leading to the doctor of pharmacy degree (Standards 2016). February 2015; https://www.acpe-accredit.org/pdf/Standards2016FINAL.pdf. Accessed May 15, 2020.

2. Rigor. Merriam-Webster.com. 2019; https://www.merriamwebster.com/dictionary/rigor. Accessed May 15, 2020.

3. Bull B. 10 Questionable ways to uphold academic rigor. 2014; http://etale.org/main/2014/09/20/10-questionable-ways-to-upholdingacademic-rigor/. Accessed May 15, 2020.

4. Draeger J, del Prado Hill P, Hunter LR, Mahler R. The anatomy of academic rigor: the story of one institutional journey. Innov High Educ. 2013;38:267-279.

5. Baulcomb JS. Management of change through force field analysis. $J$ Nurs Manag. 2003;11:275-280.

6. Accreditation Council for Pharmacy Education. Policies and procedures for ACPE accreditation of professional degree programs. January 2018; https://www.acpe-accredit.org/pdf/

PoliciesandProcedures.pdf. Accessed May 15, 2020.

7. National Association of Boards of Pharmacy. NAPLEX/MPJE candidate application bulletin. 2019; https://nabp.pharmacy/wp-content/ uploads/2019/03/NAPLEX_MPJE_Bulletin_April_2020.pdf. Accessed May 15, 2020.

8. Frick LJ, Frick JL, Coffman RE, Dey S. Student stress in a threeyear doctor of pharmacy program using a mastery learning educational model. Am J Pharm Educ. 2011;75(4):Article 64.

9. Marshall LL, Allison A, Nykamp D, Lanke S. Perceived stress and quality of life among doctor of pharmacy students. Am J Pharm Educ. 2008;72:Article 137.

10. Opoku-Acheampong A, Kretchy IA, Acheampong F, et al. Perceived stress and quality of life of pharmacy students in University of Ghana. BMC Res Notes. 2017;10:115.

11. DiVall MV, Schlesselman LS. Academic dishonesty: whose fault is it anyway? Am J Pharm Educ. 2016;80(3):Article 35.

12. Sealy PI, Williams S, Sa B, et al. Stakeholder perspectives on outcome expectations of pharmacy graduates from a Caribbean school of pharmacy. Am J Pharm Educ. 2013;77(5): Article 99. 


\section{American Journal of Pharmaceutical Education 2020; 84 (5) Article 7906.}

13. Vlasses PH, Patel N, Rouse MJ, et al. Employer expectations of new pharmacy graduates: implications for the pharmacy degree accreditation standards. Am J Pharm Educ. 2013;77(3):Article 47. 14. Zorek JA, Sprague JE, Popovich NG. Bulimic learning. Am J Pharm Educ. 2010;74(8):Article157.

15. Rudolph MJ, Daugherty KK, Ray ME, et al. Best practices related to examination item construction and post-hoc review. Am J Pharm Educ. 2019;83(7):Article 7204.

16. Hailikari T, Katajavuori N, Lindblom-Ylanne S. The relevance of prior knowledge in learning and instructional design. Am J Pharm Educ. 2008;72:Article 113.
17. Gums TH, Kleppinger EL, Urick BY. Outcomes of individualized formative assessments in a pharmacy skills laboratory. Am J Pharm Educ. 2014;78(9):Article 166.

18. Martin RD, Wheeler E, White A, Killam-Worrall LJ. Successful remediation of an advanced pharmacy practice experience: A case study of an at risk student. Am J Pharm Educ. 2018;82(9):Article 6762.

19. Wang XR, Cruthirds DL, Kendrach MG. Effect of an individualized post-examination instructor remediation on pharmacy student performance in a biochemistry course. Am J Pharm Educ. 2018;82(6):Article 6297. 